\title{
論文要旨と審査結果
}

\section{On the Transferability of Asian Rice Green Revolution to Rainfed Areas in Sub-Saharan Africa: An Assessment of Technology Intervention in Northern Ghana}

\author{
学位申請者氏名：Millicent deGraft - Johnson
}

\section{I. 論文要旨}

This study assesses the impacts of technical intervention on the adoption of five improved technologies, and the productivity and profitability of technology adoption for smallholders of lowland rice farming under rainfed conditions. The analysis was conducted based on micro-level data of 548 rice growing farmers in Northern Ghana using a multivariate adoption decision approach. The author observed that learning directly from the project increases the likelihood of adoption of fertilizer and modern variety (MVs). The information spillovers captured by the distance from the non-project village to the nearest project village was not significant in the case of the adoption of fertilizer and MVs. Close proximity of the non-project villages to the project villages, however, increases the probability of adoption of bunding and leveling. From these empirical findings, the author deduces that for observable technologies such as bunding and leveling the farmers can observe and imitate without having direct consultation with project developers or extension workers. The author also found that the early and mid-adopters of improved technology are farmers with rice farming experience and with farms closer to the homestead. The possible constraints on technology adoption are high wage rates and large farm sizes. These findings confirm the widely held perception that the adoption of improved technology results in productivity gains for the small-scale farmers. However, it must be noticed that the gain realized was much higher for package adopters than for partial adopters due to the complementary relationship among the improved technologies. These findings suggest not only that a rice Green Revolution is possible in rainfed areas of sub-Saharan Africa by introducing technology which is widely adopted in Asia and but also that investment in improved technology is a viable tool to improve the welfare of resource-poor rural households by boosting productivity in sub-Saharan Africa. 


\section{II. 審査結果報告}

審查委員 : 主査 大塚 啓二郎

委員 鈴木 綾(東京大学)

委員 櫻井 武司 (一橋大学)

委員 大山 達雄

委員 加治 佐敬(IRRI)

平成 24 年 7 月 26 日（木）の博士論文最終報告に引き続き、主查である大塚啓二郎教授、 副查である櫻井武司教授（一橋大学）、加治佐敬研究員（IRRI、国際稲研究所）、大山達 雄教授による審査委員会が開かれた。副査の一人である鈴木綾准教授（東京大学）は欠席 であったが、事前に主査に評価を伝えてあった。この審査委員会では、次のような意見が 出された。

1. サブサ八ラ諸国において水稲の生産性の潜在力の高さは、徐々に知られるようにな ってきたが、それを灌溉地帯ではなく天水田地帯で実証したことは希であり、研究 の価値は極めて高い。

2. また水稲の生産性を高める手段としての展示戋場の設置と、そこでの農民参加型の トレーニングの効果を、実証的に解明したことにも大きな評価が与えられてしかる べきである。

ただし、以下のようなコメントがよせられた。

1. 収量関数と利潤関数の推定結果に理解しがたい相違がある。この原因は究明される 必要がある。

2. Credit の役割に関する分析がない。少なくとも何らかの言及を行うべきである。

3. プロジェクトが実施されたコミュニティの選択について、より丁寧な説明が必要で ある。

4. 第 3 章での推定結果の議論では、仮説と係数の有意性の関係をより明確にすべきで ある。

5. プロジェクト実施以前から新技術を採用していたグループがいるので、推定結果の 解釈をもつと慎重にすべきである。

6. 土壌の質に関する記述的分析と、統計分析の結果に不一致が見られる。

7. 改良品種と化学肥料はプロジェクトが実施されたコミュニティ以外でもかなり採用 されており、プロジェクトコミュニティからの距離の効果についての解釈は、再考 を要する。また、プロジェクト実施中にCredit が供与されたことも考慮すべきであ る。 
8. 収量関数や利潤関数の計測で用いられている技術採用変数の意味を明確化すべきで ある。

9. 第一章と第二章がともに短く、統合す心゙きである。

10. 技術の採用の Dynamic な側面をもつと強調すべきである。

全体として、本学の博士にふさわしい内容であるという点で審查委員全員の意見が一致 し、上記の問題点を踏まえて博士論文を修正すれば、博士 (Ph. D. in Development Economics) の学位を授与すべであるという判断が下された。その後、修正された最終稿が提出され、 指摘された問題点について修正がなされていることを、審查委員会を代表して主查が確認 した。 